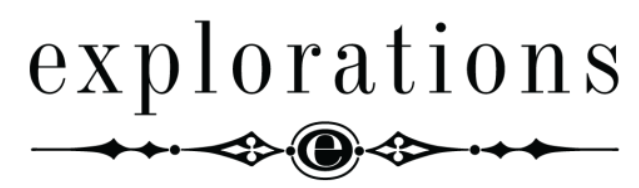

Explorations: A Journal of Language and Literature

\title{
Beyond Difference: interlingualism and the use of Spanglish in Bird of Paradise- How I Became a Latina (2013) by Raquel Cepeda and How the García Girls Lost their Accent (1991) by Julia Álvarez
}

\author{
Giorgia Scribellito (University of Warsaw)
}

DOI: $10.25167 /$ EXP13.18.6.8

\begin{abstract}
In this article I analyze interlingualism in the books Bird of ParadiseHow I Became a Latina (2013) by Raquel Cepeda and How the García Girls Lost their Accent (1991) by Julia Álvarez. I argue that interlingualism is a form of interculturalism and that it is present and vibrant in these two books. The type of interlingualism that is present is Spanglish and in particular code-switching. Spanglish is employed to a certain extent in Bird of Paradise and widely used in How the Garcia Girls Lost their Accent. In both books, however, it assumes a very significant role for the protagonists. It reflects their hybrid identity and the creation of a sense of community among bilingual speakers. I start by describing the meaning of interculturalism and compare it with multiculturalism to provide a clear definition and I proceed with an analysis of the language employed in these two texts.
\end{abstract}

Key words: interlingualism, interculturalism, multiculturalism, Spanglish, Caribbean-American literature, Latino

\section{INTRODUCTION}

In the autobiographical book Bird of Paradise- How I Became a Latina (2013) the author Raquel Cepeda employs Spanglish to communicate her personal thoughts or while speaking with Latino friends. Similarly, in How the Garcia Girls Lost their Accent (1991) the García girls and their extended family utilize Spanglish to speak to one another. This article seeks to answer the following question: "To what extent does interlingualism (or interlinguism) prove the importance of interculturalism for contemporary American society?." My answer, which is based on the analysis of the use of Spanglish in Cepeda's 
Bird of Paradise and Álvarez's How the Garcia Girls Lost their Accent, is that the use of Spanglish in these books shows that interculturalism is a powerful force in shaping identity in today American society. By contributing to foster a language that reflects different cultures interlingualism shows that interculturalism is vital and vibrant among the Caribbean immigrant community in the United States. To begin with I emphasize the difference between multiculturalism and interculturalism mostly on the basis of Tariq Mahmood's and Ted Cantle's arguments (which are two prominent theorists in this field). Grounded on this analysis I argue that interculturalism reflects a slightly different reality than multiculturalism does, which is made of a mixture of cultures. Afterwards, I conduct an analysis of Raquel Cepeda's Bird of Paradise- How I became a Latina (2013) and Julia Álvarez's How the Garcia Girls Lost their Accent (1991) from the point of view of the language used and interculturalism and I show why I consider these two books as valid and vibrant examples of an intercultural discourse.

\section{MULTICULTURALISM AND INTERCULTURALISM}

According to Tariq Mahmood, the term multiculturalism came into being in the 1960s and it started circulating in the 1970s in Canada, Australia and to a lesser degree in Britain and in the USA. In the USA it was initially limited to the field of education (Mahmood et al. 2011, 6). Mahmood argues that in the USA and in the U.K, and later in the Netherlands, multiculturalism was equated with "polyethnicity". The politics of polyethnicity focused on providing minority children and "post/neo-colonial immigrants" with an extension of the school curriculum to include " mother-tongue' teaching, non-Christian religions and holidays, halal food, Asian dress and so on" (Mahmood et al. 2011 7). From a political point of view, in Multiculturalism and Interculturalism: Similarities and Differences (2013), Martyn Barett emphasizes that another feature of multiculturalism is dual citizenship (Banting and Kymlica 2006 in Martyn Barrett 17). Furthermore, in contemporary definition, multiculturalism consists in granting to immigrants equal rights in all spheres of society. This is done without the expectation of immigrants giving up their diversity. However, there is an anticipation to conform to "certain key values" in society. (Castles, Stephen et al. The Age of Migration 248 quoted in Guiberanau, Montserrat et al ed. 2010, 213).

Even though multiculturalism is characterized by the "positive" features mentioned, according to Will Kymclica one possible threat of multiculturalism is that it fosters "a kind of mental separatism, encouraging immigrants to dwell on the life they left rather than the opportunities available in their new country" (Kymlica 2001, 167). A second challenge of multiculturalism is that it promotes illiberal practices (namely practices that violate human rights, for example when religion is used to take a conservative stand on issues of gender equality, sexual orientation, and progressive politics in general) and relativism (interculturalism in contrast, is capable to criticize and censure culture as part of intercultural dialogue) (Mahmood et al. 2011, 16-18). A third problem is that it promotes "strong ethnic or cultural identities at the expense of wider cultural exchanges." (Mahmood et al. 2011, 12).

However, as Tariq Mahmood argues in his paper "How Does Interculturalism Contrast with Multiculturalism" (2011) these problematic aspects of multiculturalism, have been challenged and there are people like Mahmood himself who still champion it 
Beyond Difference: interlingualism and the use of Spanglish in Bird of Paradise-How I Became a

because they consider it a very powerful force in society. In the article "How Does Interculturalism Contrast with Multiculturalism" Tariq Mahmood defuses the differences between multiculturalism and interculturalism and argues that the characteristics of interculturalism are foundational of multiculturalism, as well. He contends that dialogue and reciprocity are foundational of both interculturalism and of multiculturalism (Mahmood 2011, 8.).

In answer to Mahmood's argument, however, it must be observed that while is it true that dialogue and reciprocity are features of both multiculturalism and interculturalism, it is necessary to emphasize that interculturalism is more bent on a critical cross-cultural dialogue than multiculturalism, even though multiculturalism is rooted on dialogue across cultures, as well. Also, as Tariq Mahmood says, multiculturalism gives voice to marginalized groups, but not to the same extent as interculturalism does because interculturalism encourages a plurality of points of views within minority groups. Thus, through intercultural dialogue even the most repressed voices within minority groups, such as women, can find a space to express themselves.

In contrast to multiculturalism, according to Gérard Bouchard, interculturalism was inherited "from the moral awakening following the two world wars, fascism, totalitarian regimes and decolonization". It emerged in the 1950s and 1960s "as a new sensitivity towards minorities of all kinds" (Bouchard 2011, 440). Martyn Barrett in the book he edited Interculturalism and Multiculturalism: Similarities and Differences (2013) argues that interculturalism "shares a number of features with multiculturalism" (Barrett 2013, 26). However, it differs in that it emphasizes intercultural dialogue, interaction and exchange of different points of view between individuals and groups on the basis of equality. As Barrett argues, "Interculturalism proposes that intercultural dialogue helps people to develop a deeper understanding of cultural beliefs and practices that are different from their own, fosters mutual understanding, increases interpersonal trust, cooperation and participation, and promotes tolerance and mutual respect" (Barrett 2013, 26). In short, interculturalism has the objective of generating a sense of cohesiveness in society based on some shared universal values.

\section{INTERLINGUALISM: SPANGLISH}

Interlinguism is one aspect of interculturalism. The mixture of two languages such as, for example, Spanish and English, is an expression of mixing two or more different cultures by one person or in a dialogue between two people. Interlinguism, which represents the mixing of two or more cultures goes, therefore, a step further than multiculturalism, which consists in accommodating only one culture into the public space. More specifically, in a multicultural environment people of different cultures live among each other side by side but they do not actually mix. In contrast, in an intercultural environment people mix different cultures and identities and also languages.

According to Ángel López García-Mollins (2015), the name "Spanglish" was introduced by Salvador Tió, a Portoriquan intellectual, in 1948. López García-Mollins argues that according to some either Spanglish will evolve into a cultivated language or it will disappear in face of being inserted in a context where the majority is English speaking and it excludes coexistence with other languages (López García-Mollins, 2015, 9). 
However, as López García-Mollins observes, Spanglish exists and its vitality cannot be denied (López García-Mollins, 2015, 9).

According to the same author, Spanglish is not a creole language but it is a combination of two languages, Spanish and English in variable proportions according to the situations in which it is used (López García-Mollins, 2015,18). López García-Mollins observes that Spanglish is used by second and third generation immigrants to the United States with different purposes. Second generation immigrants use it to create a connection between Spanish and English but this neither means that it is an intermediate phase in the process of linguistic substitution or that it is a different language. In contrast, third generation immigrants, who speak English as their mother tongue, have Spanish as an inherited language and use Spanglish to get closer to the Spanish of their ancestors and the Anglicism and code switching with the simplification of syntactical structures make the task easier. (López García-Mollins, 2015, 27)

Citing Dumitrescu (2010) Ángel López García-Mollins identifies three types of Spanglish. One which is "characterized by the extensive use of English lexical items occurring in their original form in otherwise Spanish utterances" (Dimitrescu (2010), 225 in López García-Mollins, 2015, 38); a second one in which "English words lose their non-Spanish identity", because they "assume the morphological characteristics and inflections of Spanish words", are pronounced "to confirm to Spanish phonology" and "appear in written form spelled according to Spanish orthography" (Dimitrescu 2010, 225 in López García-Mollins, 2015, 38); a third one that "includes such things as calques, syntactic idioms, and some original expressions that can be recognized as a distinctive new form of Spanglish evolving under the influence of English, much as English itself was influenced by Norman French" (Dimitrescu 2010, 225 in López García-Mollins, $2015,38)$. We can add to this list the use of Spanish Lexical terms in otherwise English sentences, which is the case that we will analyze. López García-Mollins defines Spanglish as un "dialecto psicolngüistico", which can be translated as a "psycholinguistic dialect” (López García-Mollins, 2015, 43).

Spanglish, in this analysis is not the language of the uneducated even though as Susan Olague points out detractors of mixed languages associate them with "transitory forms of communication" (Ramos 2002, 202 in Olague 2003) that reveal "a lack of education" (Ramos 2002, 202 in Olague 2003). The protagonists of these two books by Álvarez and Cepeda are in fact very well educated. Spanglish in this case is an attempt to "address . . . the politics of multiple identities, of dispossession, objectification, marginalization, and survival" (Pascual Soler 1999, 269 in Olague 2003)

To connect interlinguism with interculturalism, in general, we can use the words of Linda De Katzew who argues that "the syncretic nature of language reflects continuous cultural changes linking past cultural nuances with present ones. Language, then, becomes a cultural tool with which individuals learn to communicate with each other" (De Katzew 2017, 65). She uses Octavio Paz's words to express the connection between language and identity and she argues that "the history and life experiences of people demand the creation of a form that will express their interpretation of their relationship with all others" (Paz 1985,165 in De Katzew 2017, 66).

As De Katzew further emphasizes, Gloria Anzaldúa notes that "ethnic identity is twin skin to linguistic identity." Anzaldúa also says "I am my language" (Anzaldúa 1987, 81 in De Katzew 2017, 73). Interlingualism and specifically Spanglish can be associated with "life at the borderlands", as Anzaldúa, a Chicana author, theorized it in her book $L a$ 
Beyond Difference: interlingualism and the use of Spanglish in Bird of Paradise-How I Became a

Frontera (1987). In this book she uses "Spanglish" because she lives on the border between two different cultures the Mexican and the American ones. According to De Katzew from California State University, Stanislaus, interlingualism or "interlinguism" as I would call it, is characteristic of the language of Chicanos and it shows "their sense of identity in the United States" (De Katzew 2017, 61). This is a very intercultural stance.

\section{BIRD OF PARADISE-HOW I BECAME A LATINA (2013)}

However, spanglish and interlinguism are not limited to the Chicano/a community and can be found in other communities such as the Caribbean-American community from Spanish-speaking regions. ${ }^{1}$ In fact Spanglish is utilized in the book Bird of Paradise: How I Became a Latina (2013) by the Caribbean-American writer Raquel Cepeda.

Cepeda was born in Harlem on June 9, 1973. She is the daughter of Dominican immigrants with her mother working as a domestic cleaner in New York City. When she was a child, Raquel moved to the Dominican Republic to live with her grandparents and she returned to New York City in 1981. She lived there with her father and her stepmother in the Inwood/Washington Heights section of Upper Manhattan. During the past twenty years Raquel has written about music, culture, fitness, politics, race and identity for publications such as People, Time Out New York, The Village Voice, CNN. Com, The New York Times and others. In the years 2001-4, she worked as chief editor of Russell Simmons One World Magazine. Her memoir Bird of Paradise How I Became a Latina was published in 2013 by Atria Books.

In Bird of Paradise Cepeda's identity can be defined as transcultural as it captures her experience of transcending cultures. Transculturalism is a form of interculturalism but with a more global meaning. Transculturalism means going/travelling/living across cultures. According to Donald Cuccioletta: "Transculturalism, places the concept of culture at the center of a redefinition of the nation-state or even the disappearance of the nation-state" (Cuccioletta 2001/2002, 9). Cepeda defines her identity as as "transnational" as it also crosses national boundaries (Cepeda 2013, 269). However, it seems to cross not only nationalities but also cultures.

Cepeda stresses how she enriches her American experience by bringing elements of her Dominican culture and how, throughout her life, she also adds to this mixture elements of other cultures, too, such as the black American culture. Holding both Dominican and American passports and feeling allegiance to the Dominican Republic and the United States, Raquel travels back and forth between the two countries. Moreover she explores her genetic background and she comes to embrace all the different identities that make it up.

\footnotetext{
${ }^{1}$ For more details about the percentage of Latinos who use "Spanglish" see the report available at https://www.scribd.com/document/27145796/Language-Use-Among-Latinosin-the-US
} 
Cepeda's transcultural identity, which is a more global form of an intercultural one, is especially important in the second part of Bird of Paradise as it encourages her to explore her father's DNA background and to learn more about her father's past and to accept it. After she is introduced to his story of abuse at the hands of his own father, which in turn led him to be abusive with his daughter, she gains a better understanding of her childhood and she understands why her father was abusive to her. Cepeda's exploration of her father's past strengthens her self-confidence and that, in turn, leads her to embrace with confidence her different identities. Moreover, it enables her to pass her story of multiple identities on to other Latino young women and to encourage them not to be ashamed of their African and Native ancestry.

In this book Cepeda creates her own fluid culture, which is a combination of multiple and different ones. She in fact is "dominiyorkian" but also black. She also recognizes herself as the product of all the different nationalities that make up her DNA. Cepeda contends that the Dominican Republic is her "holy land", her "Mecca". It is the place which is both for her an archaeological site and an ancestral shrine. America will always be foreign to her. New York City is her home. This is the place where she can construct her identity freely and reject labels imposed on her (Cepeda 2013, 259). What Cepeda means is that her identity is not fixed but changed throughout time in relation to the cities where she lived and her experiences in life. Now it is rooted in New York City but it is not a single fixed identity. Furthermore, Cepeda concludes: "Latinos are prototypical New Americans, the products of European immigration, colonialism, and slavery. What this journey [her search for her ancestral DN] has driven home for me is that being Latino means being from everywhere, and that is exactly what American is supposed to be about (Cepeda 2013, 260). Thus Cepeda recognizes the multiplicity of nationalities that is hidden behind the term Latino and the consequent complexity of this term.

Cepeda also attempts to establish a fluid history of race. She is defined in many different ways according to the people she interacts with. At home, her father accuses her of being black because she likes "graffiti and b-boys"; at school she is considered white because she plays tennis and she lives with her father's wife who is white; her friend Maria's boyfriend Casimiro tells her that she needs to embrace her native indios and African heritage; her friend Caridad lets her know that she had a vibe "of a black and white gringa" and her friend Blackie tells her that she could be from anywhere (Cepeda 2013, 117). Probably, Cepeda encompasses all these characteristics; however, what she wants is to be simply a Dominican born in Harlem (Cepeda 2013, 117).

Despite being defined in different ways according to the people she interacts with, Cepeda chooses to embrace all her identities including a black-American identity which does not truly belong to her but which she appropriates. She tries to embrace her African and native background and to find pride in it through her DNA mapping. Eventually, her DNA mapping brings peace to her identity and it gives justice to her multiple backgrounds. She in fact is one of the three million, or 6 percent, who reports multiple races to the census (Cepeda 2013, xiv). Raquel thus proves to be an intercultural person as she defies the odds of an American limiting definition of race (for example, according to the Center on Race and social Problems School of Social Work University of Pittsburgh in the future more children will be born to parents of different races and ethnicities. As a consequence, existing categories for race and ethnicity will continue to be problematic as groups outgrow and reject the classifications given to them by the U.S Census Bureau and the U.S. Office of Management and Budget. In the 2010 census, for 
Beyond Difference: interlingualism and the use of Spanglish in Bird of Paradise-How I Became a

example, detailed group examples were re-introduced for Hispanic, Asian,and Pacific Islander response categories. Children who are multiracial can identify themselves as only one race as they reach adulthood (OMB) (Davis 2010, 6-7)).

Cepeda's novel demonstrates her preference for Spanglish as the language of communication. The author uses Spanglish and she freely mixes English with Spanish she does not use mostly Spanish words mixed with English one- thus foregrounding her transnational and mixed identity as both a Dominican and an American. However she seems to valorize English as a normative language; the use of Spanish words is not extensive but occasional and she employs italics when inserting Spanish. For example, when describing her plane trip she says: "I board the plane to New York City" [...] "Legs are everywhere-thick, skinny, very light, burnt rust, like those of my primas" (Cepeda 2013, 42) and afterwards, [...] "I wonder if any of them are Dominican, like me. Or americana, like me" (Cepeda 2013, 42). It is interesting to note that in order to emphasize the lack of borders between her American and Spanish identity, Cepeda writes the word "Dominican" in English and the word "American" in Spanish.

Similarly, Cepeda utilizes Spanglish in dialogues with her Latino friends. For example she says: "Hola Casimiro. Can I watch TV in here" and Casimiro responds : "Ay coňo, I got goose bumps" [...] "When you walked in through the door, I saw one of your guides, un indio, walk in behind you." (Cepeda 2013, 93) Intermixing Spanish words in an English conversation comes naturally for Raquel and her friend Casimiro who are native Spanish Speakers, even though Raquel was born in the United States but from Spanish speaking parents.

Cepeda also utilizes Spanglish when she describes the actions of her mother and stepfather. She calls her step-father "Papito" or "Papi" and her mother "Mami". For example she considers that "Mami and Papito are at a standstill in the kitchen. He's rubbing his cheek with his right hand, and Mami's fists are balled up in front of her and she is standing like Muhammad Ali, ready to rumble" (Cepeda 2013, 37). As we can notice, Cepeda interjects Spanish nouns in an English sentence thus emphasizing her simultaneous belonging to the Spanish world and to the Anglo-American one.

On numerous occasions Cepeda points out that her manner of expression is not unique to her but part of a larger cultural phenomenon. Cepeda' mother and grandmother employ Spanglish as well to communicate to one another. For example Cepeda's grandmother, Dolores, says to her daughter, Cepeda's mother Rocío: "Rocío, coňo hombre, this guy calls way too many times" [...] "Who the hell is he?" and Rocío responds "Nadie, Mama, just a friend," (Cepeda 2013, 27). As we can see, the two older women employ Spanglish in their speech because they are native Spanish speakers but they are also acquainted with the English language. Cepeda also emphasizes that her father and step-mother speak colloquial English regulated by the rules of non-normative English.

Unlike her parents Cepeda does not have the need to become fully integrated in American society and she does not need to speak English as best as she can. Having been born in NYC and claiming the States as her "natural" home she is not that eager to pursue the American dream. Even though she speaks English perfectly well -in fact her use of Spanish words is very limited throughout the book as compared to her use of English, she does not want to forget Spanish. Spanish is part of her identity, the language of her childhood, and thus functions as a "primary language." However, she can employ it only with the limited number of Latino friends that she has. 
Cepeda's limited usage of Spanish in both her private and public life, despite her attempts to cultivate it, contrasts with that of other authors. Writers such as Gloria Anzaldua, and Junot Díaz use Spanish extensively in their writings as a vindication of the fact that their primary language is Spanish, not English. In contrast to Cepeda, for example, Díaz in The Brief Wondrous Life of Oscar Wao (2007) uses an English root with a Spanish suffix or a Spanish root with an English suffix to signify the confusion brought about by the two languages in the mind of the protagonist, Oscar Wao, as well as to point out to the usage of a colloquial Spanglish by the protagonist. ${ }^{2}$ Nevertheless, Cepeda employs Spanglish in her book precisely because she wants to communicate to the reader the complexity of her identity and her belonging to simultaneously these two worlds (the Dominican Republic and the United States) like other Latino/as authors (in other words she wants to vindicate her interculturalism). It is also evidence of a rebellion against social norms that require English to be the only language spoken by people living in the United States even though the society comprises people who come from different linguistic and cultural backgrounds. Her rebellion is also directed against the promotion in the United States of a uniform Anglo-Saxon identity. We can, therefore, argue that Cepeda's intertlingualism is an expression of her interculturalism. It is evidence of her belonging simultaneously to more than one culture.

\section{HOW THE GARCÍA GIRLS LOST THEIR ACCENT (1991)}

In a similar vein Julia Álvarez uses Spanglish in How the García Girls Lost their Accent (1991) to show the intercultural background of the Garcia family. Álvarez and her family arrived in New York City on August 6, 1960 while escaping the tyranny of the dictator Rafael Trujillo. Álvarez grew up in Queens in a middle class environment. At the age of 13 , she was sent to a private boarding school in the United States and later she attended Connecticut college and eventually earned an M.F.A from Syracuse University. After her graduation she took a job with the Kentucky Arts Commission as a travelling poet-in-residence. Homecoming was her first book of poetry, published in 1984. In 1996 a second edition was released, which was entitled Homecoming New and Collected Poems. In 1995 she published another book of poetry: The Other Side/El Otrolado. In 1991 she was offered a tenure track position at Middlebury College in Vermont. She began writing fiction in 1977 and her stories "Father" and "The Rainfall" appeared in print; however it was only in 1991, that her first novel -"How the Garcia Girls Lost Their Accents" - was published (Ciria Bados 114). Her second novel In the Time of the Butterflies was published in 1994. She subsequently wrote other novels that feature characters from the Dominican Republic.

"How the Garcia Girls Lost Their Accents" (1991) is an autobiographical novel and one of Álvarez's most famous books. Originally the individual chapters were conceived as separate stories and they appeared in magazines, anthologies, and journals as early as 1983. They were slightly different from the novel (Sirias 2001, 17). The book narrates the story of four girls, Carla, Sandra, Yolanda and Sofia García and their parents Doňa Laura and Don Carlos who, like Álvarez and her parents, emigrate from the Dominican

\footnotetext{
${ }^{2}$ See DomnitaDumitrescu (2014) for a discussion of the use of Spanglish in JunotDíaz
} 
Beyond Difference: interlingualism and the use of Spanglish in Bird of Paradise-How I Became a

Republic to the United States to escape the dictator Rafael Trujilo's secret police. The book is divided into three parts: 1989-1972, 1970-1960 and 1960-1956 with the first part focusing on the adult life of the four sisters; the second part is centered around their immigration to the United States and their adolescence; the third part is a recollection of their early childhood on the island (Sirias 2001 19).

Like Raquel Cepeda's family in Bird of Paradise (2013) the García family comes from a district called El Paraíso in the capital of the Dominican Republic and they emigrate to New York City, in the Bronx. The two books tell very different stories. As we have mentioned, Cepeda's story is very troubled by internal and external conflicts. In contrast, the García girls' story is apparently much simpler. They migrate to New York City thanks to a medical fellowship awarded to their father and despite a difficult time adjusting to life in the United States and the initial economic hardship they face, they eventually succeed in going to prep school and then college and in getting married, amidst divorcing. The four girls eventually adjust to American life and they accomplish the American dream, which is what they sought for. However, as in Bird of Paradise the parents speak Spanglish in the United States and the García girls do so in the United States, as well as in the Dominican Republic. This usage of Spanglish shows that the family is troubled by an internal conflict between the two cultures, the Dominican one and the American one, like Raquel Cepeda. They are an intercultural family.

The García girls deal with this conflict by trying to embrace American life as much as possible. They smoke Marijuana and they are advocates for women's rights. In college, they try to fit in with their American classmates. Yet, Yolanda cannot embrace the sexual freedom that she sees in the new country, she is true to her Catholic heritage. Also, she is made fun of by her classmates because she misses the double meanings of her compositions. Two of the girls (Yolanda and Sandra) end up in a mental health hospital for a period of time. At a private mental hospital Yolanda translates instantaneously some passages from Don Quijote into English. This is probably a sign of the difficulties she encounters adapting to the new country and to the new language and this is why she is obsessed with translation. She claims at the hospital that she broke up with her boyfriend John because they did not speak the same language (Alvarez 1991, $80 \mathrm{ff}$.). Sandi, instead, is sent to the mental hospital because she believes that soon enough she will turn into a monkey. For this reason, she thinks she has to read all the great works because her brain is the only thing left of her humanity. Even though it may seem a psychotic problem, it may, nevertheless be the result of her difficult cultural adaptation to the new society. Sandi's problems in fact arise in college where she is studying human evolution, something which she may have not been acquainted before having studied in Catholic schools, where, most likely, they do not teach Darwin's evolutionary theories.

The parents, too, live in between the American culture and the Dominican one and they also try to adjust to American life but to a lesser extent than their daughters. For Carlos and Laura García "the hidden agenda [for their daughters ] was marriage to homeland boys, since everyone knew that once a girl married an American, those grandbabies came out jabbering in English and thinking of the island as a place to go get a suntan" (Álvarez 1991, 109). Laura, in particular, tries to exercise control over the good reputation of her daughters and over their behavior but she also enjoys the greater personal freedom that she has as a woman in the United States, as opposed to the Dominican Republic, and she does not want to go back to the Dominican Republic either. 
Carlos instead reads the Spanish newspapers every day while trying to succeed professionally: "On his side of the bed her husband would be cooked out for an hour already, his Spanish newspaper draped over his chest, his glasses propped up on his bedside table, looking out eerily at the darkened room like a disembodied bodyguard" (Álvarez 1991, 134) At first, Carlos hopes to go back to live in the Dominican Republic but he changes his mind when he sees that there is no hope for political change in the Republic. The parents like their daughters are forced due to the circumstances in which they find themselves to find a compromise between their Dominican culture, which is a natural part of them and their newly acquired American one.

This book is much less introspective than the autobiography by Raquel Cepeda and the focus is much more on social class than on internal conflicts. For this reason the family has a harder time embracing their interculturalism. Nevertheless, as we have mentioned, interculturalism is apparent in the parents' use of Spanglish in the United States, even though the mother, Laura, has been educated in the United States and she speaks English almost without a heavy accent. In other words, they cannot run away from their Dominican culture even though they live in the United States. The García girls' parents utilize Spanglish to express their simultaneous belonging to the Dominican Republic and their need to slowly incorporate the American culture. For example, the father, Carlos, calls his wife "Mami" and the mother, Laura, calls her daughters and her niece "Cuquita" Or "Cuca" (Álvarez 1991, 37, 42, 58, 66, 136, 148 ) and her husband "Cuco" (Álvarez 1991, 139, 144) in the midst of English sentences. She comments to her husband: "Ay, Cuco! Remember how I showed you that suitcase with little wheels so we should not have to carry those heavy bags when we travel? Someone stole my idea and made a million!" (Álvarez 1991, 139-140). She then adds: "See, see! This man was no bobo [stupid n.d.a]! He didn't pull all his pokers on a back burner." 3 Also the mother calls her daughter Carla "Seňorita Miss Carla" while recounting a story about a pair of white sneakers that Carla and her father Carlos had painted red with nail polish (Álvarez 1991, 37,44). Furthermore, when Yolanda is hospitalized in the mental hospital, Laura comments "probrecita Yosita"... "We love you" to make her daughter feel her affection even though Yolanda feels that her name has been "bastardized" because she is not called with her nickname "Yo" but with her full Spanish name, which she feels is demeaning (Álvarez 1991, 81). In the second part of the book Carlos decides that he will become a "dominican-york" when he sees that there are no hopes of political changes in the Dominican Republic and he takes the pledge to become a fully-fledged American citizen and precisely: a Dominican who lives in New York city (Álvarez 1991, 107).

In contrast, Spanglish is used by the four girls- Yolanda, Sofia, Carla and Sandra- in the United States to express their combined belonging to the Dominican culture, as well as to the American one. For example, the girls called their father "Papi", which reflects their ties to the Spanish language" (Álvarez 1991, 30, 37). Yolanda resorts to the use of Spanish especially when she feels threatened: "Yo rhymes with Cielo in Spanish "....Cielo, cielo the word echoed. And Yo was running, like mad into the safety of her first tongue, where the proudly monolingual John could not catch her, even if he tried " (Álvarez 1991, 73). Yolanda seems to be almost ashamed of speaking Spanish as her mother tongue, but she realizes that it is a great resource in times of need. During this

\footnotetext{
3 Please note that "bobo" means stupid in Spanish (Álvarez 140)
} 
Beyond Difference: interlingualism and the use of Spanglish in Bird of Paradise-How I Became a

episode she realizes that John, her lover, will never be able to penetrate her world, which is made of the Spanish culture and eventually she breaks up with him. She tells her parents that she broke up with him because they did not speak the same language. Furthermore, interculturalism is apparent when the little Fifi says "Gracias" to the American couple, the Fannings, who have invited the García family to dinner to a fancy restaurant in New York City (Álvarez 1991, 191). It is also evident when Yolanda calls her mother "Mami" and her grandmother "Mamita" (Álvarez 1991, 275, 276). A humorous episode occurs when the four girls dedicate themselves to translating the names of relatives from Spanish into English: "Tía Concha became Aunt Conchshell, and tía Asuncion, Aunt Ascensión, Tío Mundo was Uncle World, Paloma, our model cousin turned into Pigeon" (Álvarez 1991, 111). This episode shows, once again, the double worlds/standards (Spanish and Americans) in which the García girls live.

The four girls do not use Spanglish only in the United States but also in the Dominican Republic, even though their mother tongue is Spanish. This is probably because they are not used to communicating with each other in Spanish, and also they do not want to forget English terms while in the Dominican Republic, so they resort to a combination of the two languages. For example, Sofia tells to her sisters the story of Manuel Gustavo, her boy-friend and she says that "his father is our father's brother, Tío Orlando, who has a half dozen children from una mujer del campo, a woman from the countryside, around one of his ranches. Of course, Tía Fidelina, our uncle's wife, who is sweet and dedicated to La Virgen "knows nothing" about Tío Orlando's infidelities" (Álvarez 1991, 118-119).

Lastly, as Silvio Sirias notes, How the Garcia Girls Lost Their Accents contains a large amount of "toying with proverbs in translation -from Spanish to English" to express this simultaneous belonging to the Spanish and the English-speaking worlds (Sirias 2001, 34) In this novel, you can find Spanish expressions translated into English such as "No hay moros en la costa" (Álvarez 1991, 86), "Con paciencia y calma hasta un burro sube la palma" (Álvarez 1991, 138), "Mi casa es su casa" (Álvarez 1991, 203) and "En la boca cerrada no entran moscas" (Álvarez 1991, 209). This book is less unconventional than Bird of Paradise and much more focused on living according to strict social class norms. Nevertheless, it shows once more than Caribbean-American authors use interlingualism to express interculturalism or an hybrid identity.

\section{CONCLUSIONS}

In conclusion the use of Spanglish in both Raquel Cepeda's and Julia Álvarez's books show that there is a different kind of migration to the United States: not only the traditional multicultural one that is made up of people speaking one language at home and learning a different one at school, growing up with two separate identities one in the community and family and one in school but also the migration of people who grow up with a mixture of identities both at school and outside: an intercultural identity.

If multiculturalism is the simultaneous existence of different cultures and interculturalism is the mixing of different cultures, Caribbean-American Literature shows that interculturalism is as important as multiculturalism. In particular the books by Raquel Cepeda and Julia Álvarez show that Spanglish, which is a form of 
interculturalism, is a valuable way of living for immigrants to the United States. The characters in these two books seem to take pride in speaking Spanglish and to use it as a form of solidarity among bilingual speakers.

As Martyn Barrett, argues in the book he edited Interculturalism and Multiculturalism: Similarities and Differences (2013) interculturalism "shares a number of features with multiculturalism" (Martyn Barrett 2013, 26). However, it differs in that it emphasizes intercultural dialogue, interaction and exchange of different points of view between individuals and groups on the basis of equality. Interculturalism can be found in different forms: one of them is interlingualism as we have seen.

This study can be enhanced through an analysis of interlingualism and interculturalism in other Caribbean-American and Latino authors to show that immigrants have a hybrid (intercultural identity) and that they use interlingualism to manifest it.

\section{REFERENCES}

Aluma-Cazorla, Andrés. (September 2014). "The Gay Immigrant and the Use of Spanglish in Ángel Lozada's "No quiero quedarme sola y vacía": A Linguistic Transgression or a Struggle to Assimilate in the Late Capitalist City?" Hispania. Vol. 97 No.3: 364-365.

Álvarez, Julia. 1991. How the García Girls Lost Their Accent. Chapel Hill: Algonquin Books.

Antonisch, Marco. 2016. "Interculturalism versus Multiculturalism -The Cantle-Modood debate", Ethnicities, Vol.16 (3): 470-493.

Anzaldúa, Gloria. 1999. Borderlands/La Frontera: The New Mestiza. San Francisco: Aunt Lute Books.

Appiah, K. Anthony. 9.10.1997. "The Multiculturalist Misunderstanding”, The New York Review of Books: 30-36.

Bala, Saroj. July 2015. "Multicultural Literature in the Age of Globalization", International Journal of Multicultural Literature. 5.2:.6-12.

Barrett, Martyn. 2013. "Introduction-Interculturalism and multiculturalism: concepts and controversies" in Interculturalism and Multiculturalism: Similarities and Differences. Edited by Martyn Barrett, 15-41. Strasbourg: Council of Europe Publishing.

Bouchard, Gérard. 2011. "What is Interculturalism", McGill Law Journal, Vol. 56, issue $2: 435-468$. Print.

Cantle, Ted. 2008. 'Parallel Lives' in Citizenship, Cohesion and Solidarity (Smith Institute:). Web. 1 Dec. 2018

Casielles-Suárez, Eugenia.dic 2017,,Spanglish: la voz híbrida de los latinos en los Estados Unidos."Atlantis (0210-6124)Vol. 39 Issue 2, p147-168

Cepeda, Raquel. 2013. Bird of Paradise: How I Became Latina. New York City: Atria Books.

Ciria, Bados, Concepción. 2017. Carribean Identity and Migrancy: The Novels of Julia Álvarez: 113-121.Web. July 15.

Corbatta, Jorgelina. Sep 2014 "An Imaginary Dialogue between Gloria Anzaldúa and Julia Kristeva”. Hispania., Vol. 97 Issue 3: 362-363.

Cuccioletta, Donald. "Multiculturalism or Transculturalism: Towards a Cosmopolitan 
Beyond Difference: interlingualism and the use of Spanglish in Bird of Paradise-How I Became a Latina (2013) by Raquel Cepeda and How the Garcia Girls Lost their Accent (1991) by Julia Álvarez 101

Citizenship" London Journal of Canadian studies 2001/2002 v. 17.

Czainska, Katarzyna. 2015 "Where Does Interculturalism Begin? Studies of Selected Examples of Women's Modern Literature", Global Management Journal. Vol.7, issue 1/2: 5-13.

Davis, Larry E. and Bangs, Ralph. 2010. "Race in America- Restructuring Inequality". Paper presented at The Third of Seven Reports on the Race in America Conference. June 3-6 , 2010 http://www.crsp.pitt.edu/sites/default/files/RaceRelationsReport_ 001. pdf

Di Gregorio, Rita et al. 2003. Arcipelago Mangrovia- Narrativa Caraibica e Intercultura. Bologna: EMI.

Dumitrescu, Domnita. September 2014. "English-Spanish Code Switching in Literary Texts: Is it still Spanglish as We Know it ?" Hispania, Vol. 97,Number 3: 357-359.

Guiberanau, Montserrat et al. Ed. 2010. The Ethnicity Reader: nationalism, multiculturalism and migration. Cambridge, etc: Polity Press Print.

Harbeck, James. Fall 2002 "The transcendent function of interculturalism", Studies in the Literary Imagination, Vol. 34 Issue 2: 13-15.

Katzew, Linda De. Sept. 2017. "Interlingualism: The Language of Chicanos/as" (April 1, 2004). National Association for Chicana and Chicano Studies Annual Conference. Paper. http://scholarworks.sjsu.edu/cgi/viewcontent.cgi? article=1022\&context=naccs. (Accessed September 2017)

Kimlica, Will. 2001. Politics in the Vernacular: Nationalism, Multiculturalis and Citizenship. Oxford, New York: Oxford University Press.

Laugier, Régine ed. 2010. Intercultura, Interculturalità- dalla Teoria alla Pratica. Rubbettino: Rubettino ed.

López García, Ángel. 2015.Teoría del Spanglish. Valencia: Tirnat Humanidades.

Mahmood, Tariq et al. 2011 "How Does Interculturalism Contrast with Multicuturalism", Journal of Intercultural Studies 19 Dec: 1-22.

Maldonado, Ledezma, Ictzel. 2011. "Estados-Nación, Identitades Subalternas e Interculturalismo en América Latina". Revista Lider, Vol 18 Ano13. : 53-67.

Modood, Tariq. 2014. "Multiculturalism, interculturalism and the Majority". Journal of Moral Education, vol. 43, No. 3: 302-315.

Molina-Naar, José. 8 March 2016. "Current Sociopolitical, Sociocultural, and Sociolinguistic Issues of Latino Immigrants in Julia Álvarez's Novel How the García Girls Lost Their Accents", Journal of Latinos and Education, 15:3. 253-258.

Olague, Susan. "Towards New Dialects: Spanglish in the United States" 2003 http://homes.chass.utoronto.ca/ cpercy/courses/6362Olague2.htm (accessed 29.06.2017)

Paz, Octavio. 1985. The Labyrinth of Solitude. New York: Grove Weidenfeld, in Linda de Katzew. Sept. 2017. "Interlingualism: The Language of Chicanos/as". (April 1, 2004). National Association for Chicana and Chicano Studies Annual Conference. Paper 6. http://scholarworks.sjsu.edu/cgi/viewcontent.cgi?article=1022\&context= naccs

Raab, Josef et al. 2013. Interculturalism in North America. Tempe, Az: Bilingual Press.

Sirias, Silvio. 2001. Julia Alvarez: A Critical Companion. Westport, Connecticut, London: Greenwood Press 
Snyder, Daniel. December 17, 2016. „Estás ready?: A look at "Spanglish" in the UnitedStates" Panoramas. http://www.panoramas.pitt.edu/art-and-culture/\%C2 $\%$ BFest\%C3\%A1s-ready-look-spanglish-united-states (accessed 29.06.2018)

Taylor, Charles. 1992. Multiculturalism and "The Politics of Recognition". Princeton: Princeton University Press.

This work is licensed under the Creative Commons Attribution 3.0 Unported License. http://creativecommons.org/licenses/by/3.0/

AUTHOR'S BIO: Giorgia Scribellito is currently a PhD student at the English Institute of University of Warsaw, focusing on American Literature. Her dissertation discusses interculturalism in the books of four Caribbean American writers: Jamaica Kincaid, Audre Lorde, Julia Álvarez and Raquel Cepeda.

E-MAIL: gscribellito@yahoo.it 